\title{
GYDYTOJO - PACIENTO SĄVEIKA: TAPSMAS EPILEPSIJA SERGANČIU PACIENTU
}

\author{
Jurgita Tuitaitė \\ Vytauto Didžiojo universitetas
}

Raktažodžiai: epilepsija, pacientas, paciento ir gydytojo sąveika, kokybinis tyrimas.

\begin{abstract}
Santrauka
Epilepsija - nenuspejjama liga. Sunku numatyti priepuolio laiką ir pasekmes, todèl pacientui, gydytojo kabinete išgirdusiam šią diagnozę, nelengva suprasti, kaip pasikeis jo gyvenimas. Susitikimų su gydytojais metu pacientas mokosi pažinti šią ligą, nuolat reflektuojant apie kūno pokyčius ir gydymo eigą. Naujausi epilepsija sergančių asmenu gyvenimo kokybės tyrimai rodo bendravimo ir bendradarbiavimo su sveikatos priežiūros specialistų komanda svarbą. Tyrimo tikslas - atskleisti, kaip epilepsija sergantys žmonès mokosi gyventi su liga gydytojo-paciento sąveikos kontekste. Pasirinkta konstruktyvistinès grindžiamosios teorijos koncepcija, taikant K. Charmaz versiją [4]. Atliktas kokybinis tyrimas. Taikytas teorinès imties sudarymo principas. Tyrimui atrinkti epilepsija sergantys suaugusieji, kuriems šis susirgimas diagnozuotas ne anksčiau nei prieš penkerius metus, neturintys pažintinių funkcijų sutrikimų. Duomenų rinkimo metodas - pusiau struktūruotas interviu. Interviu duomenys transkribuoti ir koduoti, formuotos kategorijos. Tyrimo metu rašytos atmintinès, naudotos duomenų analizès metu. Apklausta 10 epilepsija sergančių asmenų.

Tyrimas atskleidè, kad pacientams ligos pradžioje sunku suprasti epilepsijos priepuolių priežastis, diagnostikos ir gydymo priemones dèl išgyvenamo nerimo ir ligos neigimo. Pacientams susitaikius su epilepsijos diagnoze, pradedamas ugdyti diadinis pasitikejjimo gydytoju jausmas, sergantieji motyvuojami išgirsti gydytojo nurodymus ir juos vykdyti, mokomi atpažinti veiksnius, skatinančius priepuolių atsiradimą. Kuriant pasitikejjimu ir atsakomybe grịstus diadinius gydytojo ir paciento santykius, pacientas tampa aktyviu, nuolat besimokančiu asmeniu. Tyrimo metu konstruota grindžiamoji teorija, paaiškinanti paciento mokymosi gyventi su liga proceso etapus, kurią sudaro trys centrinès kategorijos: 1) „Aš“ - susipažini-
\end{abstract}

mas su epilepsija, siekiant suprasti paciento patirtị, tik diagnozavus epilepsiją; 2) „Ašc - atsiverimas sau, siekiant rekonstruoti paciento išgyvenimus, pradejus mokytis gyventi su liga; 3 ) „Aš“ - atsiverimas kitam, siekiant susitikimų su gydytoju metu suprasti paciento vaidmeni ligos gydymo procese.

\section{Ivadas}

Epilepsija yra lètinis neurologinio pobūdžio, biopsichosocialinis sutrikimas [3], pasireiškiantis pasikartojančiais epilepsijos priepuoliais, kurių laiką ir vietą sunku numatyti. Ši liga dažnai diagnozuojama kartu su kitomis, tokiomis kaip galvos smegenų traumos, navikai, protinis atsilikimas ir kita. Tyrimai rodo, kad diagnozavus epilepsiją, mokymasis gyventi ja sergant tampa iššūkiu asmens tapatumui [6]. Asmens tapatumas kinta ne tik dèl biologinio kūno pasikeitimų, bet ir dèl nuolat veikiančiu psichosocialinių veiksnių, tokių kaip stresas, baimé patirti priepuolius, negalejjimas suprasti ligos priežasčių, netikrumas dèl ateities [8]. Ankstesnieji tyrimai parodè, kad sergančiojo epilepsija diadinis santykis su gydytoju konstruojamas pasitelkiant kalbą ir socialinius gebejjimus [7,9], veikiamus antiepileptinių medikamentų ir priepuolių, todèl dažnai gydytojui sunku suprasti paciento socialinį elgesị, turintị ịtakos gydymo eigai. Tyrejai pastebejo, kad gydymą trikdo ir paciento sąmoningas nutylëjimas apie priepuolius, nepasitikejjimas skirtu gydymu [3].

Šiuo metu gydytojo bendravimas su epilepsija sergančiu asmeniu kinta ir dèl technologijų atsiradimo: internete, socialiniuose tinkluose sergantieji dalijasi savo patirtimi apie gyvenimą sergant šia liga, todèl keičiasi ir gydytojo-paciento santykiai [9]. Vis dažniau organizuojamos sergančiujų epilepsija edukacinès programos didina pacientų sąmoningumą ir prisideda prie sveikatos priežiūros paslaugų kokybès gerinimo [8]. Tyrimai parodè, kad organizuojami mokymai, rengiama dalomoji medžiaga, stengiantis sukurti erdves, kuriose sergantieji savo patirtis galètų aptarti su sveikatos priežiūros specialistais [9]. Mokslininkai pastebi, kad sergančiujų epilepsija didžiausia problema - išmokti kalbèti apie 
ligą ir tapti aktyviu diadinio dialogo su gydytoju dalyviu [5].

Tyrimo tikslas - atskleisti, kaip epilepsija sergantys žmonès mokosi gyventi su liga gydytojo-paciento sąveikos kontekste.

\section{Tyrimo medžiaga ir metodai}

Siekiant atskleisti, kaip epilepsija sergantys žmonès mokosi gyventi su liga gydytojo - paciento sąveikos kontekste, pasirinkta konstruktyvistinès grindžiamosios teorijos koncepcija, taikant K. Charmaz versiją. Grindžiamoji teorija tai induktyvus metodas, ịgalinantis konstruoti teoriją iš gautų kokybinių duomenų [4]. Kokybiniai duomenys gaunami laikantis apibrèžtų duomenų rinkimo procedūrų, nesiremiant kitomis griežtomis konstrukcijomis ar teorijomis apie reiškinius. Formuojant konstruktyvistinę grindžiamają teoriją, taikyta socialinio konstravimo paradigma. Socialinès realybès konstruktyvistine teorija pagal P. Berger ir T. Luckmann (1966) apibrěžia ,žinojimą“" ir „tikrovę“, kur „žinojimas“ aiškinamas kaip tikrumas, o „tikrové“ - fenomenų savybė. Atliktas kokybinis tyrimas. Taikytas teorinès imties sudarymo principas. Tyrimui tikslingai atrinkti sergantys epilepsija suaugusieji, kuriems ne anksčiau nei prieš penkerius metus diagnozuotas šis susirgimas. Epilepsija labai dažnai būna ir gretutinè liga, šalia ịvairių raidos sutrikimų bei sunkių neurologinių traumų, sutrikdančių ir pažinimo funkcijas, todèl atrinkti tiriamieji, kuriems nenustatyti pažintinių funkcijų sutrikimai. Tyrimo duomenų rinkimo metodas - pusiau struktūruotas interviu. Apklausta 10 epilepsija sergančių asmenų. Interviu duomenys transkribuoti ir koduoti, formuotos kategorijos. Tyrimo metu rašytos atmintinès, naudotos duomenu analizès metu. Tyrimo dalyvių vardai pakeisti.

\section{Tyrimo rezultatai}

Analizuojant tyrimo duomenis, suformuotos trys pagrindinès kategorijos: 1) „Aš“ - susipažinimas su epilepsija; 2) „A $\breve{s}^{“}$ - atsiverimas sau; 3 ) „Ašs“ - atsivėrimas kitam. Šiomis kategorijomis apibūdinama sergančiojo epilepsija patirtis gydytojo-paciento sąveikos kontekste.

Pirmoji kategorija. „Aš゙“ - susipažinimas su epilepsija. Sergantieji epilepsija pažymi, kad išgirdę diagnozę tiesiog išklause gydytoją, tikèjosi ligos atsitraukimo, išgyveno ligos neigimo fazę. Ligos neigimo metu siekiama „būti normaliu“, laukiama, gal išnyks priepuoliai ir bus galima gyventi „,iprastinị, normalų“ gyvenimą, tačiau priepuoliams kartojantis, pradedama ieškoti informacijos: „Tai tada ieškojau informacijos, klausinejau taip ir giminiu, gal ka žino apie ta liga " (10). Pirmą kartą diagnozavus epilepsiją, pacientai patiria nerimą dèl neapibrežtumo, nes nèra supažindinti su diagnostiniais tyrimais, gydymo būdais: ,, pradžioje eidavau taip su nerimu, nes nežinai ka išgirsi. Ypač va kaip būdavo tyrimai. Pirma karta gal labiausiai bijojau, nes nesuvokiau “ (4). Pacientai pastebi, kad trūksta psichologo, su kuriuo galètų kalbètis apie ligą, mokytis suprasti, kaip pasikeis jų socialinis gyvenimas.

Duomenų analizès metu buvo stebimi epilepsija sergančiųų tyrimo dalyvių pasakojimų konstravimo ypatumai. Pastebèta, kad tik susirgę tiriamieji kalba apie ligą kaip objektą, kurio nenori pripažinti ir pažinti, kuris tarsi turètų išnykti, jei nebus kreipiamas demesys į ligą. Mokymasis apie ligą padeda suvokti ją kaip gyvenimo dali, kuri nèra atskiras, kažkur sklandantis objektas, todèl stebimas „Aš sergu epilepsija“" santykio kismas - epilepsijos priepuolio virsmas subjektyviu patyrimu.

Antroji kategorija. „Aš“ atsivẻrimas sau. Po pirmujų apsilankymų pas gydytoją, formuojama strategija, kaip priepuolius paversti gyvenimo dalimi: pirmiausia, mokomasi atpažinti kūno signalus, rodančius priepuolio pradžią bei socialinę aplinką, skatinančią priepuolių atsiradimą. Vèliau - siekiama ịgyti žinių, skaitoma įvairi literatūra, tačiau pastebima, kad gydytojas yra pagrindinis informacijos šaltinis ir mokytojas. Ligos pradžioje gydytojas padeda atpažinti ligą skatinančius veiksnius ir nurodo kryptį, ką reikètų stebèti, nes svarbiausia - išsiaiškinti priepuolių priežastis: „tai svarbu atsakyti buvo kodèl tie priepuoliai“"(1).

Ligos pradžioje sergantieji nežino, ką reikia sakyti gydytojui, kaip apibūdinti ligą ir mano, kad svarbiausia tyrimai, kad tik tyrimų rezultatai atsakys į visus klausimus ir padès pasveikti. Epileptologui diagnozavus ligą ir paaiškinus tyrimo rezultatus, pradedama ieškoti informacijos ịvairiose knygose, tinklapiuose: ,,nu internetas kaip internetas pilnas ir ko reik, ir ko nereikia, ten gali prisiskaityt ir jurginais gali gydytis. Nereikètu pasikliauti šia informacija" (3), o nesuradus atsakymų vèl kreipiamasi ị gydytojus: „tai labai daug žiniu dave profesoré viena iš kliniku ir labai daug žiniu pasisèmiau, ten" (8).

Rekonstruojant praeities įvykius, pastebimi pozityvūs elgesio modeliai, kurie padeda atpažinti veiksnius, sukeliančus priepuolius, todèl pradedama pasitikèti savimi: , $\mathrm{kad}$ reikia išlikti ramiai ir jeigu bandysiu išlikti ramiau - tada pasveiksiu, paskui atsimenu pradejau labai pasitikèt savim" (10). Atsivėrimas sau apibūdinamas kaip pripažinimas to, kas neišvengiama, t.y. nuolatinis savęs stebëjimas, vizitai pas gydytojus, siekis valdyti priepuolius.

Trečioji kategorija. „Aš“ - atsivèrimas kitam. Epilepsija sergantys tiriamieji pasakojimuose atskleidè bendradarbiavimo su gydytoju svarbą, siekiant ligos atsitraukimo, tačiau nurodè ir bendradarbiavimui būtiną sąlygą - diadinị bendradarbiavimą, t.y. pacientas, atvirai pasakojantis apie savo ligą, kasdieni gyvenimą ir gydytojas, skiriantis gydymą ir kalbantis su pacientu apie medikamentu poveiki, gydymo 
sékmę, atsakantis ị klausimus. Reflektuojant apie vizitus pas gydytojus, pastebima, kad jam reikia „viską pasakoti“, todèl kiekvieno susitikimo metu tiriamieji stengèsi paminèti visus su liga susijusius veiksnius. Sergantieji apsilankymo pas gydytojus metu patyre ne tik gydytojo profesionalo medicininę pagalbą, bet ir atjautą žmogaus, suprantančio paciento kančią ir bejègiškumą. Konstruojamas dialoginis pokalbis su gydytoju leido stebėti gydytojo žmogiškąsias pastangas padèti asmeniui, net ir neveikiant medikamentiniam gydymui - ieškota būdų sumažinti priepuolių dažnį. Gydytojas suvokiamas kaip savo srities profesionalas, tačiau atsakomybė dèl gydymo eigos suprantama kaip paciento atsakomybè, „,nes gydytojas negali žinoti visko, gydytojas tik žmogus, todèl gali klysti, sergantysis - ligos ekspertas, todèl reikia nuolat stebèti save“ (9).

Apibendrinant galima pastebèti, kad epilepsijos gydymo sèkmė veikiama gydytojo-paciento sąveikos kokybės: pacientas atvirai pasakoja apie ligą, prisiima atsakomybę už ligos valdymą, patirdamas empatiško gydytojo pagalbą.

\section{Diskusija}

Tyrimo dalyviai, susirgę epilepsija, ne iškart išgirdo gydytoją, nes sužinojus diagnozę atsirado neigimas, buvo manoma, kad netiesa, kad tai ne epilepsija, kad nereikalingas gydymas bei mokymai, kaip gyventi sergant šia liga. Tiriamieji ligos pradžioje atvirai nepasakoja savo problemų gydytojui, nes jaučia nerimą dėl ateities, priepuolių baimę ir nežinomybę, kaip išmokti gyventi sergant šia liga. Nuolat reflektuojant apie gyvenimą su šia liga ir sẻkmingą gydymą, laipsniškai formuojamas profesionalaus gydytojo paveikslas. Gydytojo, ne tik ịgijusio specializuotų žinių, bet ir jautraus pacientų problemoms ir norinčio padèti. Mokymasis valdyti ligą prasideda formuojantis suvokimui apie ligą kaip neišvengiamą tikrovès dalị, kurią svarbu ne tik pažinti, atpažinti bet ir mokytis gyventi sergant. Dialoginio santykio su gydytoju metu formuojamas pasitikejjimas gydytoju, pradedama suprasti sergančiojo atsakomybė už gydymo efektyvumą. Sergantieji, nors ir ilgą laiką, nuolat mokosi pasakoti gydytojui apie savo ligą. Tai nenutrūkstamas procesas, nes keičiant gydymą, gyvenimo būdą, keičiasi ir informacijos poreikis.

\section{Išvados}

1. Pacientams ligos pradžioje sunku suprasti epilepsijos priepuolių priežastis, diagnostikos ir gydymo priemones dèl išgyvenamo nerimo ir ligos neigimo.

2. Pacientui pripažinus savo susirgimą epilepsija, pradedamas konstruoti diadinis pasitikejjimo gydytoju jausmas, stengiamasi išgirsti gydytojo nurodymus ir juos vykdyti, mokytis atpažinti socialinès aplinkos veiksnius.

3. Konstruojant pasitikèjimu ir atsakomybe grisstus dia- dinius santykius, pacientas, aktyviai ir nuolat mokydamasis iš empatiško gydytojo perteikiamų žinių, įgalinamas valdyti ligą.

\section{Literatūra}

1. Bhugra D, Malik A. Professionalism in mental healthcare: experts, expertise and expectations. Cambridge University Press 2010. https://doi.org/10.1017/CBO9780511910074

2. Bošnjak Pašić M, Horvat Velić E, Fotak L, Pašić H, Srkalović Imširagić A, Milat D, Šarac H, Bjedov S, Petelin GadŽe Ž. Many faces of d'ej'a vu: a narrative review. Psychiatria Danubina 2018;30(1): 21-25.

https://doi.org/10.24869/psyd.2018.21

3. Caplan R. Epilepsy, language, and social skills. Brain and language 2019;193:18-30.

https://doi.org/10.1016/j.bandl.2017.08.007

4. Charmaz K. Constructing grounded theory: A practical guide through qualitative analysis. Sage Publications 2006.

5. Charon R. The principles and practice of narrative medicine. Oxford University Press 2017.

https://doi.org/10.1093/med/9780199360192.001.0001

6. Kılınç S, Campbell C, Guy A, van Wersch A. Epilepsy, identity, and the experience of the body. Epilepsy Behav 2018;89:42-47. https://doi.org/10.1016/j.yebeh.2018.10.003

7. Petrocchi S, Iannello P, Lecciso F, Levante A, Antonietti A, Schulz PJ. Interpersonal trust in doc-tor-patient relation: Evidence from dyadic analysis and association with quality of dyadic communi-cation. Soc Sci Med 2019;235(112391): 112391-112391.

https://doi.org/10.1016/j.socscimed.2019.112391

8. Rawlings GH, Brown I, Stone B, Reuber M. Written accounts of living with epilepsy: A themat-ic analysis. Epilepsy Behav 2017;72: 63-70.

https://doi.org/10.1016/j.yebeh.2017.04.026

9. Schachter SC. Successful health communication in epileptology. Seizure 2017;44:7-10.

https://doi.org/10.1016/j.seizure.2016.10.005

10. Spiciarich MC, von Gaudecker JR, Jurasek L, Clarke DF, Burneo J, Vidaurre J. Global health and epilepsy: update and future directions. Curr Neurol Neurosci Rep 2019;19(6):30. https://doi.org/10.1007/s11910-019-0947-6

\section{PHYSICIAN/PATIENT INTERACTION: BECOMING PATIENT WITH EPILEPSY}

\section{J. Tuitaitè}

Keywords: epilepsy, patient - doctor interaction, qualitative research.

Summary

Epilepsy is a serious disease of its unpredictability: it is difficult to predict the time and consequences of seizure. Although epi- 
lepsy is an invisible condition and the first hearing this diagnosis in a doctor's office makes it difficult for a person to understand how his or her life will change. Patients have to learn how to live with epilepsy during the visits with the doctors. They learn to know the disease by constantly reflecting on the changes in the body, the course of treatment, and the factors of the social environment. In order to improve the quality of life of such individuals, recent research has focused on communication and collaboration with a team of healthcare professionals. A qualitative study has been conducted in Lithuania to reveal how people with epilepsy learn to live with the disease in the context of doctor-patient interaction. A grounded theory approach involving ten adult with epilepsy was used to explore their experiences of learning to live with epilepsy in the context of doctor-patient interaction. Data were collected using interview. Using grounded theory systematic inductive process data of analysis, the core findings consisting of three central categories emerged. The first category, "I" meeting with the epilepsy, let us understand patients' experiences after being diagnosed. Second,
"I" open to myself, "I am a patient", let us to reconstruct patients the starting point of learning to live with epilepsy. The Third category, "I" opening up to another, let us understand the patient's role during the interactions with doctors. The study revealed that patients at the onset of the disease have difficulty to understand the causes of epileptic seizures, diagnostic and treatment measures for surviving anxiety and disease rejection. When patients accept epilepsy they starting to construct dyadic relations througth trust and self-responsibility. The people with epilepsy listen to the doctor's instructions and follow them and reflect social environment factors. By constructing a dyadic relations based on trust and responsibility, the patient becomes an active, constantly learning person from an empathetic physician.

Corespondence to: jtuitaite@yahoo.com

Gauta 2021-07-09 